\title{
Projections of climate change in streamflow and affluent natural energy in the Brazilian hydroelectric sector of CORDEX models
}

\section{Projeções de mudanças climáticas na vazão e energia natural afluente sobre o setor hidroelétrico brasileiro dos modelos do CORDEX}

Marx Vinicius Maciel da Silva ${ }^{1}$ (D), Cleiton da Silva Silveira ${ }^{1}$ (D), Greicy Kelly da Silva ${ }^{1}$ (D), Wanderson Hugues de Vasconcelos Pedrosa ${ }^{1}$ (D), Antônio Duarte Marcos Júnior ${ }^{2}$ (D) \& Francisco de Assis Souza Filho ${ }^{1}$ (D)

${ }^{1}$ Universidade Federal do Ceará, Fortaleza, CE, Brasil

${ }^{2}$ Universidade Estadual do Ceará, Fortaleza, CE, Brasil

E-mails: marx.silva@alu.ufc.br (MVMS), cleitonsilveira@ufc.br (CSS),greicykellysilvagks@gmail.com (GKS),wandersonhvp@gmail.com (WHVP), duarte.jr105@gmail.com(ADMJ), assis@ufc.br (FASF)

\begin{abstract}
Long-term water and energy planning makes it possible to reduce social and economic impacts by avoiding episodes of interruption in water and electricity supply, essential services for several sectors. Thus, the analyses proposed by this study aimed at identifying the impact of climate change on naturalised streamflows and Affluent Natural Energy (NEA) projections for the Brazilian electricity sector using six models of the Coordinated Regional Climate Downscaling Experiment (CORDEX) project, based on the RCP 4.5 and RCP 8.5 scenarios for the 21 st century. The streamflows for the 24 stations representing the National Interconnected System (NIS) were estimated through the concentrated hydrological model SMAP (Soil Moisture Accounting Procedure), while the streamflows for the other stations that comprise the NIS were obtained by linear regression. The streamflows, as well as the productivity of the reservoirs, were used to calculate the NEA. The results showed that most of the models project possible reductions in annual naturalized streamflows and NEA for the three periods analyzed and for the North, Northeast and Southeast/Midwest sectors. Meanwhile, in the Southern sector, for the period 2010-2039, most of the models indicated an increase in the annual naturalized streamflows and NEA.
\end{abstract}

Keywords: Streamflow; Affluent natural energy; National interconnected system; 21st century.

\section{RESUMO}

O planejamento hídrico e energético a longo prazo possibilita reduzir impactos sociais e econômicos, pois evitam episódios de interrupção do fornecimento de água e energia elétrica, serviços essenciais para diversos setores. Desse modo, as análises propostas pelo presente estudo visaram identificar o impacto das mudanças climáticas nas projeções das vazões naturalizadas e Energia Natural Afluente (NEA) para o setor elétrico brasileiro utilizando seis modelos do projeto Coordinated Regional Climate Downscaling Experiment (CORDEX), baseados nos cenários do RCP 4.5 e RCP 8.5 para o século XXI. As vazões para os 24 postos representativos do Sistema Interligado Nacional (NIS) foram estimadas através do modelo hidrológico concentrado SMAP (Soil Moisture Accounting Procedure), enquanto as vazões para os demais postos que compõem o NIS foram obtidas por regressão linear. As vazões, em conjunto com a produtividade dos reservatórios, foram utilizadas para o cálculo da NEA. Os resultados mostraram que a maioria dos modelos projetam possíveis reduções das vazões naturalizadas e NEA anuais para os três períodos analisados e para os setores Norte, Nordeste e Sudeste/Centro-Oeste. Enquanto que, no setor Sul, para o período de 2010-2039, a maioria dos modelos indicaram aumento das vazões naturalizadas e da NEA anuais.

Palavras-chave: Vazão; Energia natural afluente; Sistema interligado nacional; Século XXI. 


\section{INTRODUCTION}

Modern economies need a reliable and affordable supply of electricity for the entire population, as it is a parameter of economic and social development degree. According to the International Energy Agency (2020), the electricity consumption growth is expected to exceed energy consumption as a whole in the next 25 years. However, along with an increase in electricity demand, there are changes in the global electricity power systems driven by the reality of climate change. Therefore, protecting the environment and meeting the needs of the economy become the great challenge for sustainable development.

In Brazil, the National Interconnected System (NIS), which is responsible for the production and transmission of electricity, is a large hydrothermal-eolic system with a predominance of hydroelectric plants (Operador Nacional do Sistema, 2020). Studies show how climate change may have major impacts that directly affect soil moisture, groundwater reserves and streamflow seasonality due to changes in spatial and temporal patterns of precipitation and evapotranspiration in the country (Guimarães et al., 2016; Silveira et al., 2016; Sales et al., 2015). Such aspects, associated with projections of increased demand for water and energy in the next decades, caused mainly by population and wealth growth, may exert great pressure on the Brazilian hydrosystems, affecting water and energy supply and consequently the entire national economy (Fernandes et al., 2017; Prado et al., 2016).

In 2017, for example, due to unfavorable climatic/hydrological conditions, there was a $3.4 \%$ reduction in the available hydraulic energy compared to the previous year (Empresa de Pesquisa Energética, 2018). In order to supply this deficit, the thermal power plants, in general located near the main load centers, are activated. Their role is important to ensure future service and they are dispatched according to the current hydrological conditions. However, they make use of fossil fuels, acting as positive feedback for global warming and climate change. Hence, there is an interdependence or "link" between climate, water and energy (Al-Mutrafi et al., 2018; Pardoe et al., 2017; Scanlon et al., 2017; Zhang et al., 2018; Zhou et al., 2019).

Long-term hydro and energy planning makes it possible to reduce social and economic impacts on various sectors, and avoids episodes of interruption in the electricity supply that, for instance, occurred from years 2000 to 2002 throughout the country. Therefore, the projections of streamflow and Affluent Natural Energy (NEA) - the energy that defines the power generation potential of a hydroelectric system, associated with the impacts of climate change in the 21 st century - emerge as important information for the Brazilian electricity sector when providing possible impacts on long-term electricity generation.

In this context, the Intergovernmental Panel on Climate Change (IPCC) is, internationally, the leading scientific body for assessing the impacts associated with climate change - having been created by the United Nations Environment Programme (UNEP) and the World Meteorological Organization (WMO) in 1988 (Intergovernmental Panel on Climate Change, 2014).

Since its creation, the IPCC has been releasing Assessment Reports (AR) on climate change, releasing projection scenarios (which include the present scenario, future scenarios, paleoclima simulations, and idealized simulations) - using
Global Climate Models (GCM - General Circulation Model) - based on Greenhouse Gas (GHG) emissions (Intergovernmental Panel on Climate Change, 2014). However, in order to compare the various models, all simulations follow a pattern, from input data to simulations, through groups that cooperate with one another in the Intercomparison Model Project (CMIP - Model Intercomparison Projects), having an association with the World Climate Research Programme (WCRP).

In its fifth phase (CMIP5), projections based on scenarios called Representative Concentration Pathways (RCP) were made. RCP are sets of projections of the radiative forcing components of anthropogenic nature, used as input data in the GCM for atmospheric climate and chemical modeling (Intergovernmental Panel on Climate Change, 2014). For the estimation of these forcers, the Greenhouse Gases contribution was used as a criterion (Intergovernmental Panel on Climate Change, 2014). Thus, in the Fifth Assessment Report published in 2014, the IPCC generated the following scenarios for the end of the $21 \mathrm{st}$ century: RCP 3.0-PD (Peak and Decline), peaked in the radiative force at $3 \mathrm{~W} / \mathrm{m}^{2}$ in the middle of the 21 st century decreasing to $2.6 \mathrm{~W} / \mathrm{m}^{2}$ by 2100 , also called RCP 2.6; RCP 4.5 with stabilization at $4.5 \mathrm{~W} / \mathrm{m}^{2}$ before the end of the 21 st century; RCP 6.0 with stabilization at $6 \mathrm{~W} / \mathrm{m}^{2}$ after 2100 ; and RCP 8.5 with increasing path, reaching $8.5 \mathrm{~W} / \mathrm{m}^{2}$ in 2100 and $12 \mathrm{~W} / \mathrm{m}^{2}$ after the $21 \mathrm{st}$ century (Intergovernmental Panel on Climate Change, 2014; Sales et al., 2015).

Using data from these CMIP models, coupled with hydrological models, several studies have analized the projections of the climate change impact on water and energy resources in South America and especially in Brazil (Gondim et al., 2018; Ho et al., 2016; Mendes et al., 2017; Ribeiro Neto et al., 2016; Oliveira et al., 2017; Sorribas et al., 2016; Silveira et al., 2019). In the work of Oliveira et al. (2017), for example, the impacts of climate change on streamflows and hydropower potential in the Rio Grande basin headwaters, southeastern Brazil, were evaluated. For this purpose, data from a regional model forced by two models from CMIP5, HadGEM-ES and MIROC5, for RCP 4.5 and RCP 8.5 scenarios in the period from 2007 to 2099 were used. The results indicated a significant reduction in streamflows and hydroelectric potential during the analyzed period for both scenarios.

However, for risk studies, adaptation and mitigation strategies related to climate change, smaller scale information (regional and local) the GCMs do not include are needed (Guimarães et al., 2016; Sales et al., 2015). To this end, refinement techniques are commonly used, such as dynamic downscaling, where GCM results are used as input to force Regional Climate Models (RCM). In order to standardize the simulations with this technique, as in CMIP5, regional modeling groups follow a standardized methodology related to the CORDEX project (Coordinated Regional Climate Downscaling Experiment), those simulations are divided over some regional domains around the globe that cover continents partially or entirely.

Thus, CORDEX results present two sets of simulations: (i) the validation of the RCMs, in which they are forced by observational data from ERA-Interim (Reanalysis of ECMWF, European Centre for Medium-Range Weather Forecast); and (ii) climate projections forced by CMIP5's GCM which, 
in turn, are divided into Historical (having as reference the current climate) and simulations of future climate scenarios, in which the Downscaling of RCP 4.5 and RCP 8.5 is prioritized in this study.

Using these results, several studies have shown the good performance of the CORDEX RCM models at representing the main climatic variables and possible future impacts on climate and water resources in different regions (Guimarães et al., 2016; Reboita et al., 2018; Sales et al., 2015). Among these works, Guimarães et al. (2016), using CORDEX and CMIP5 results for Northeastern Brazil, showed that the average of the data sets of precipitation, air temperature near the surface, Potential Evapotranspiration (ETP), and Aridity Index (AI) variables produces a significant representation of the recent climate (1985-2005), with special emphasis on the CORDEX SPCs, which presented the greatest correlations. In addition, the average of the models indicated an increase in ETP, AI and temperature between $2.1{ }^{\circ} \mathrm{C}$ and $4{ }^{\circ} \mathrm{C}$ for RCP4.5 and RCP8.5, respectively, during the period 2079-2099.

Thus, this study aimed at evaluating CORDEX projections for streamflow and NEA for NIS based on the RCP 4.5 and RCP 8.5 scenarios. Assuming that data modeled with higher spatial resolution, through dynamic downscaling, favor the representation of local climatic phenomena that directly influence rainfall rates and, consequently, the streamflow and production of electricity in Brazil.

\section{METHODOLOGY}

In order to evaluate the climate change projections of CORDEX for the hydroelectric stations in Brazil, streamflows and NEA of the NIS were analyzed based on RCP 4.5 and RCP 8.5. A methodology was necessary to choose the representing basins of the NIS, obtaining data of naturalized streamflows until the final NEA calculation - a process that was divided into six stages.

In stage 1, the choices of the representing NIS hydrographic basins were made. For this, 24 stations of some Hydroelectric Power Plants were used for the generation of 24 hydrographic basins, as shown in Figure 1.

In stage 2 , the time series from monthly spatial averages over the 24 basins of the variables of precipitation, the mean, minimum and maximum Surface Air Temperatures (SAT) of the CORDEX RCM related to Historical scenarios (1951-1999), RCP 4.5 and RCP 8.5 (from 2006 until the end of the 21 st century), and observational precipitation of the Global Precipitation Climatology Centre (GPCC), and the mean, maximum and minimum SAT of the Climate Research Unit (CRU) were extracted, both in the period 1931-2018. With the observational and numerical mean, maximum and minimum series of SAT using the HargreavesSamani method.

In stage 3, statistical corrections for bias removal were performed using the gamma distribution function of data obtained/estimated precipitation/ETP from CORDEX scenarios

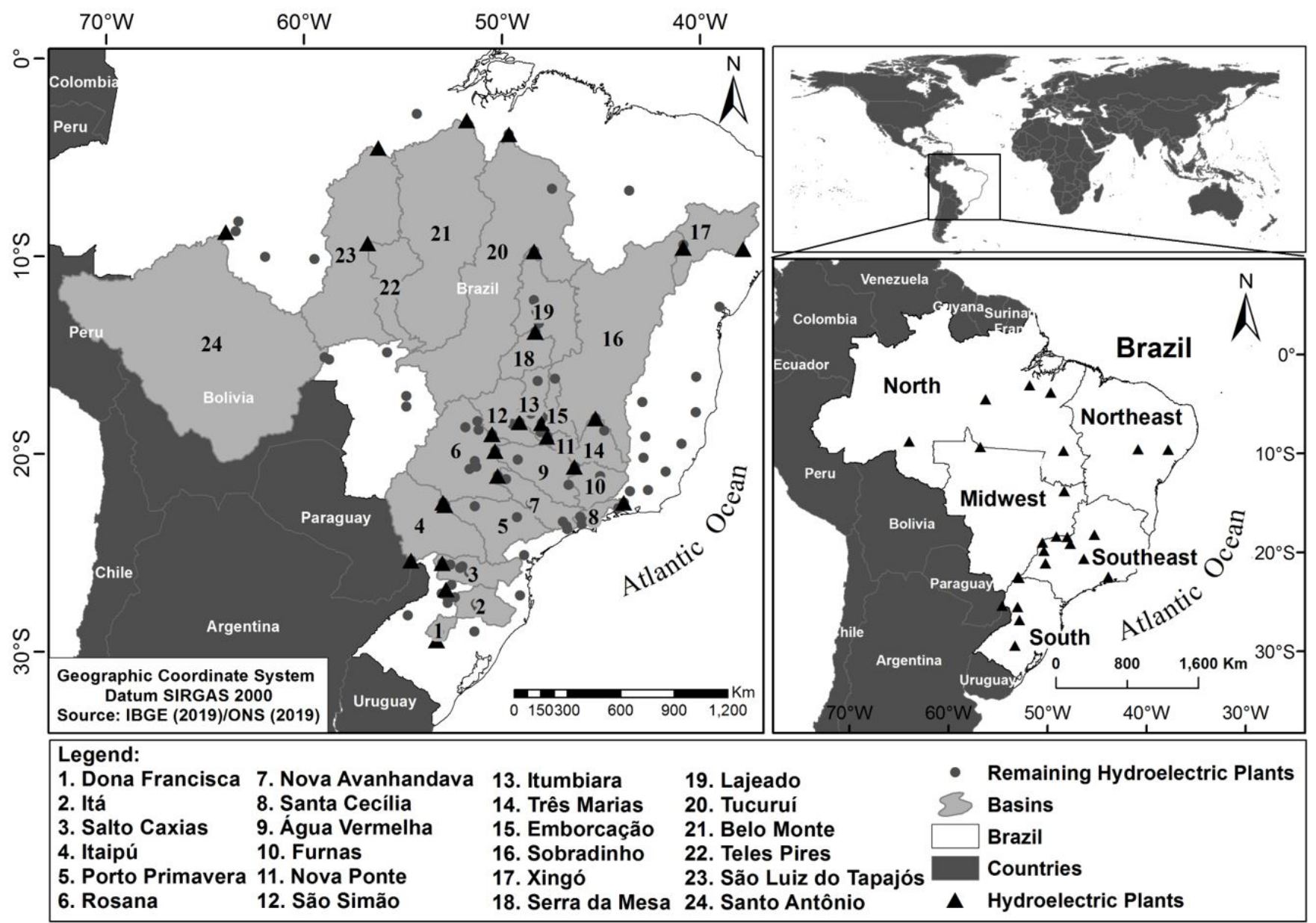

Figure 1. Study Region with the Hydrographic Basins representing the NIS. 
based on the observational precipitation and ETP data obtained and estimated from the GPCC and CRU, respectively.

In stage 4, ETP data and precipitation with bias removed from CORDEX are used as input by the SMAP hydrological model to generate streamflow data from the NIS representative basins. For that, the SMAP model had its parameters calibrated using selected data from the stations of the National Institute of Meteorology (INMET) from 1992 to 1999 (precipitation, insolation, temperature, humidity). In addition, an objective optimization procedure was used based on the Nash-Sutcliffe coefficient, which compares the natural streamflow series obtained by SMAP with the series provided by the National Power System Operator (ONS) - for more details see subtopic "SMAP Hydrological Model."

Stage 5 consisted of estimating streamflow data for the remaining gauging stations, which do not have the calibrated SMAP model. For this, the monthly regression method is used based on the streamflow data generated with the SMAP model and the monthly naturalized streamflow series made available by the ONS. Thus, the ONS naturalized streamflow data are divided into two groups: one with 24 stations and the other with 161, in which the 24 gauging stations are used as a predictor of the other station streamflows. Thus, it was possible to obtain the regression parameters of the 185 gauging stations by using Stepwise.

In stage 6, Affluent Natural Energy (NEA) was calculated through natural streamflows and productivity equivalent to $65 \%$ of the useful storage volume of hydroelectric plant reservoirs.

All stages, as well as the description of the study area, data used, and statistical analyses performed, will be discussed in the next topics.

\section{Study areas}

Figure 1 shows the hydrographic basins representing the NIS, the hydroelectric plant stations and subsystems. The hydrographic basins, with the exception of the Santo Antônio river basin, are fully included in Brazilian territory.

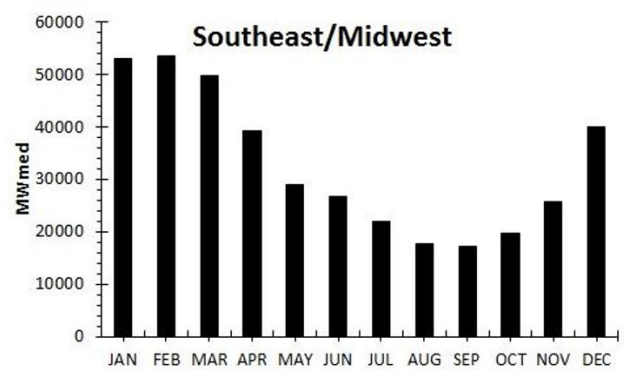

a)

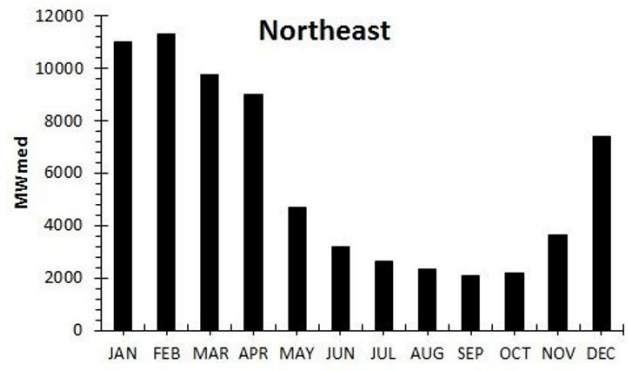

c)
The Serra da Mesa, Lajeado, Tucuruí, Belo Monte, Teles Pires, São Luiz do Tapajós and Santo Antônio hydrographic basins are located in the Northern region. In the Southeast/Midwest sector, the most demanding sector in the country, the Itaipú, Rosana, Porto Primavera, Nova Avanhandava, Santa Cecília, Furnas, Água Vermelha, São Simão, Itumbiara, Nova Ponte, Emborcação and Três Marias hydrographic basins are located. In the South sector, the Dona Francisca, Itá and Salto Caxias hydrographic basins are located, and they take partial demand from the Southeast/Midwest region. In the Northeast region, the Sobradinho and Xingó are hydrographic basins are located.

Due to its large size and locations of the plants, the NIS is influenced by several meteorological phenomena, resulting in a great spatial and temporal variability with seasonal, interannual and decadal behaviors distinct from the rains (Silveira et al., 2016). Among the meteorological phenomena that may contribute to the seasonal variability of precipitation and consequently to the streamflow and energy over the NIS, the Intertropical Convergence Zone (ITCZ), South Atlantic Convergence Zone (SACZ), Mesoscale Convective Complex (MCC), Low Level Jets (LLJ) and the Cold Front (CF) stand out.

ITCZ is the main large-scale atmospheric phenomenon influencing the rains in the equatorial Atlantic region, with an important role in the short rainy season in Northeastern Brazil, especially from December to May, when it is positioned further south (Reboita et al., 2010); as a consequence, it is possible to observe that the highest values of NEA are presented in this period, according to Figure 2c. The ITCZ also influences the Northern region of Brazil, where the humid air brought by it undergoes orographic lifting on the Andes, supporting convective activity and precipitation with maxims in summer and austral autumn (Capozzoli et al., 2017; Reboita et al., 2010), when the NEA values are higher (see Figure 2d). The Southeast and Midwest regions have a well-defined rainfall system from October to February - a

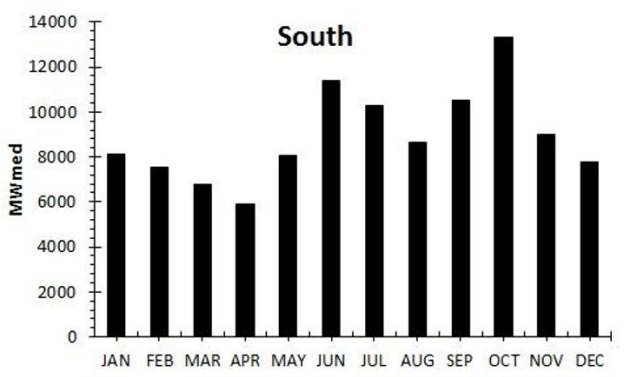

b)

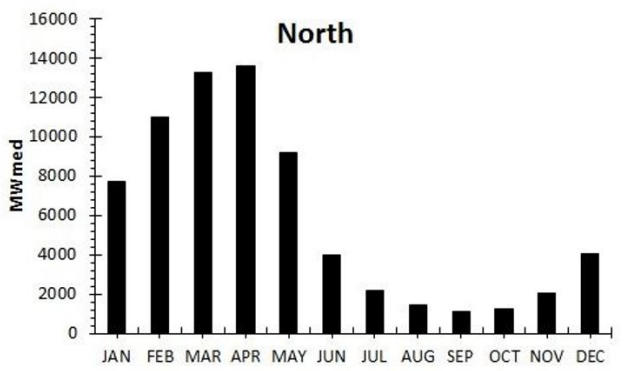

d)

Figure 2. NEA in MWmed (the unit used is the relationship between the generated power and the operating time of the facility) of the Brazilian electricity sector subsystems: (a) Southeast/Midwest; (b) South; (c) Northeast; and (d) North. From 2000 to 2017. 
period when it has the highest values of NEA (see Figure 2a) -, influenced mainly by the presence of SACZ and LLJ, with minimum rainfall occurring from July to September, with lower values of NEA (Reboita et al., 2010). The Southern region has CF and $\mathrm{MCC}$ as the main cause of rainfall throughout the year, which is an exception compared to the other regions that present a rainy and a dry season (Reboita et al., 2010). That's why the NEA values in this region have a lower seasonal variation in comparison to the other subsystems (see Figure 2b).

Thus, due to this distinction in rainfall variability and NEA, the NIS is divided into four subsystems, they are: Southeast/Midwest, South, Northeast and North. They are interconnected by an extensive transmission network that permits surplus energies to be transferred, assisting the optimization of stocks stored in the reservoirs of hydroelectric plants.

\section{Observational data}

For gamma statistical correction, monthly observed data in the period $1901-2013$ with spatial resolutions of $0.5^{\circ} \times 0.5^{\circ}$ from GPCC precipitation variables (Schneider et al., 2017) and mean, maximum and minimum SAT of the CRU were used. In order to calibrate the parameters of the Rain-Streamflow SMAP model, an observed database obtained from INMET containing monthly variables of precipitation, insolation, temperature, and humidity in the period 1992-1999 was used, so was the ONS monthly naturalized streamflow in the period 1931-2008. The ONS streamflow rates were used for the linear regression model and for the NEA calculation, likewise the reservoir productivity data obtained from the ONS, as well.

\section{CORDEX data}

CORDEX data result from simulations of RCM Rossby Centre regional atmospheric model version 4 (RCA4) for the South America domain (SAM-44, 18.75N-58.25S and 16.25 W-106.25W), through dynamic downscaling technique. Such technique is used to increase spatial resolution of CMIP5 GCMs data, utilizing them as boundary conditions of the RCM simulations, resulting in data with a grid of $0.44^{\circ} \times 0.44^{\circ}$ (approximately $50 \mathrm{~km}$ ).

RCA4 is developed at the Swedish Meteorological and Hydrological Institute (SMHI). During its development, the simple transfer and applicability to any global domain is a priority, with no need of data readjustment (Kjellström et al., 2016). In the simulations, 40 vertical levels were used in the sigma-z hybrid coordinates and
Bechtold Kain-Fritsch convection scheme, which separates surface and deep convection processes (Kjellström et al., 2016).

For this study, the monthly variables of precipitation, mean, maximum and minimum SAT were used for RCP 4.5 and RCP 8.5 projections from year 2006 to the end of the 21 st century. The simulation configurations are standardized by institutes in "rxiypz" format codes, in which " $r$ " stands for the rounds, " $\mathrm{i}$ " for initializations, and " $\mathrm{p}$ " for physics disturbances, that is, for a r1i1p1 model there are round 1,1 initialization, and 1 physics disturbance. Table 1 presents the GCM models that have forced the RCA4 RCM, each model code, and the institutions or organizations with their respective countries.

\section{ETP estimation using the Hargreaves-Samani Method}

For the ETP estimation, the observational data of the CRU and RCM from the projection of RCP 4.5 and RCP 8.5 scenarios of the mean, maximum and minimum SAT variables (in Celsius degrees) were used, using the Hargreaves-Samani method (Hargreaves, 1994), according to Equation 1:

$$
\mathrm{ETP}=0.0023\left(\mathrm{SAT}_{\text {máx }}-\mathrm{SAT}_{\text {min }}\right)^{0.5}\left(\mathrm{SAT}_{\text {med }}+17.8\right) \mathrm{Ra}
$$

where ETP is given in $\mathrm{mm} / \mathrm{month}$; and the Average External Radiation ( $\mathrm{Ra}$ ) was estimated from latitude and month of the year, according to Hargreaves' (1994) study.

\section{Statistical correction using the accumulative distribution function range}

For impact studies, such as the present one, the direct data from climate models are not usually utilized due to the elevated errors when in comparison to the observed data (Ramirez-Villegas \& Khoury, 2013). According to Volosciuk et al. (2017), the main problem related to the climate model predictions concerns bias. Thus, the statistical correction via gamma Cumulative Distribution Function (CDF) with probability mapping is performed in the monthly time series of precipitation and ETP of the CORDEX RCM for the 24 basins representing the NIS.

This model has been successfully used in several studies that analyse the climatic and hydrological variables, mainly for corrections of modeled precipitation data, although, it can also be applied in the estimated ETP (Fernandes et al., 2017; Silveira et al., 2016, 2019).

Table 1. Models considered for the study of the projections of the RCP 4.5 and RCP 8.5 scenarios.

\begin{tabular}{|c|c|c|}
\hline Models & Codes & Institution or organizations (Countries) \\
\hline CSIRO-Mk3-6-0 & r1i1p1 & $\begin{array}{l}\text { Commonwealth Scientific and Industrial Research Organization in collaboration with Queensland Climate } \\
\text { Change Centre of Excellence (Australia) }\end{array}$ \\
\hline ICHEC-EC-EARTH & r2i1 1 & Irish Centre for High-End Computing (Ireland) \\
\hline IPSL-CMSA-MR & r1i1p1 & Institut Pierre-Simon Laplace (Paris) \\
\hline HadGEM2-ES & r1i1p1 & Met Office Hadley Centre (United Kingdom) \\
\hline NCC-NorESM1-M & r1i1p1 & $\begin{array}{l}\text { Integrated Earth System Approach to Explore Natural Variability and Climate Sensitivity (EarthClim) and } \\
\text { Research Council of Norway (Noruega) }\end{array}$ \\
\hline NOAA-GFDL-ESM2M & r1i1p1 & National Oceanic and Atmospheric Administration and Geophysical Fluid Dynamics Laboratory (United States) \\
\hline
\end{tabular}


In this study, two gamma CDF functions were necessarily used due to the elaboration of the probability mapping for the bias correction in the monthly time series of precipitation and ETP of the CORDEX RCM for the 24 basins representing the NIS; the first function was obtained through modeled data and the second through observed data. Each created CDF fit to a gamma distribution, except for the format and scale parameters. Twelve gamma adjustments were considered, one for each month of the year, that is, all precipitation/ETP that occurred during every month of January are grouped, and the parameters are generated. Then, the same procedure is performed for the other months.

Due to this fact, it was possible to check the probabilistic behavior of the modeled data in relation to those observed with the generated accumulated probability distribution curves. Therefore, the corrected precipitation/ETP value of the CORDEX RCM was obtained by taking the precipitation/ETP value corresponding to the equal probability of occurrence on the observed values curve. Fang et al. (2015) provides more information on the statistical correction method through the gamma CDF.

\section{The SMAP hydrological model}

The monthly SMAP model was developed in 1981 (Lopes et al., 1981). This model operates by performing the hydrological balance in two reservoirs: one on soil and the other underground, these being hypothetical. As a result, the state variables are updated monthly. To that end, their input parameters (soil saturation capacity, streamflow, and reload) receive an assignment of values that suggest the existence of water, stored in reservoirs, in the initiation period of simulation. The water stored in each reservoir is updated at each time interval due to the incorporation of a new average data of rain, through transfer equations, totaling 4 functions. Thus, Es stands for surface runoff $(\mathrm{mm}), \mathrm{P}$ precipitation $(\mathrm{mm})$, Tu the initial moisture content (adimensional), Er the actual evapotranspiration, Ep the potential evapotranspiration ( $\mathrm{mm}$ ), Pes the surface runoff parameter (adimensional), Crec the reload coefficient (adimensional), Eb the base runoff ( $\mathrm{mm}), \mathrm{K}$ the recession constant (month-1), Rsolo the soil reservoir, Rsub the underground reservoir, and Rec the underground recharge; transfer functions are given by:

$$
E_{s}=f_{1} \cdot P
$$

where $f_{1}=T_{u}{ }^{P}$.

$\mathrm{E}_{\mathrm{r}}=\mathrm{f}_{2} \cdot \mathrm{E}_{\mathrm{p}}$

being $\mathrm{f}_{2}=\mathrm{T}_{\mathrm{u}}$.

$$
\mathrm{R}_{\mathrm{ec}}=\mathrm{f}_{3} \cdot \mathrm{R}_{\text {solo }}
$$

where $\mathrm{f}_{3}=\mathrm{C}_{\mathrm{rec}} \cdot \mathrm{T}_{\mathrm{u}}{ }^{4}$.

$$
E_{b}=f_{4} \cdot R_{\text {sub }}
$$

where $\mathrm{f}_{4}=1-\mathrm{K}$.

Figure 3 shows a schematization of how the monthly SMAP model works.
In this work, the calibration took place in a single step, in which the parameters of Soil Saturation Capacity (SSC), Surface Runoff (SR) and Reload Coefficient - the parameter associated with permeability in the unsaturated soil zone (Crec) and the rate of deplection $(\mathrm{K})$ of the Rsub level that generates the $\mathrm{Eb}$ - have undergone optimization through the solver tool from Microsoft Excel spreadsheet, followed by a manual refinement of trial and error. The mean rainfall ( $\mathrm{mm} / \mathrm{month})$, the observed streamflow rate $\left(\mathrm{m}^{3} / \mathrm{s}\right)$, potential evapotranspiration $(\mathrm{mm} / \mathrm{month})$ and the basin area $\left(\mathrm{km}^{2}\right)$ were the input data initially entered. In addition, two other variables of state had their values initialized, being that: the initial soil moisture rate (MRin), which determines the initial level of Rsolo, and the Initial Base runoff (BFin), which defines the initial value of the Rsub, that were manually adjusted based on the calculated values for the Nash-Sutcliffe Efficiency Coefficient (NASH) at each simulation.

$\mathrm{NASH}$ is an objective function that measures the efficiency of adjustment between an observed model and observed data, being one of the most adopted/used criteria in Hydrology (Andrade et al. 2017). According to the formulation presented by Nash \& Sutcliffe (1970) and considering $\mathrm{N}$ as the number of samples, $o_{i}$ as the data observed, $m_{i}$ as the modeled data, and $\overline{o_{i}}$ as the average of the observed data, NASH is calculated through Equation 6:

$$
\mathrm{NASH}=1-\frac{\sum_{\mathrm{i}=1}^{\mathrm{N}}\left(\mathrm{o}_{\mathrm{i}}-\mathrm{m}_{\mathrm{i}}\right)^{2}}{\sum_{\mathrm{i}=1}^{\mathrm{N}}\left(\mathrm{o}_{\mathrm{i}}-\overline{\mathrm{o}_{\mathrm{i}}}\right)^{2}}
$$

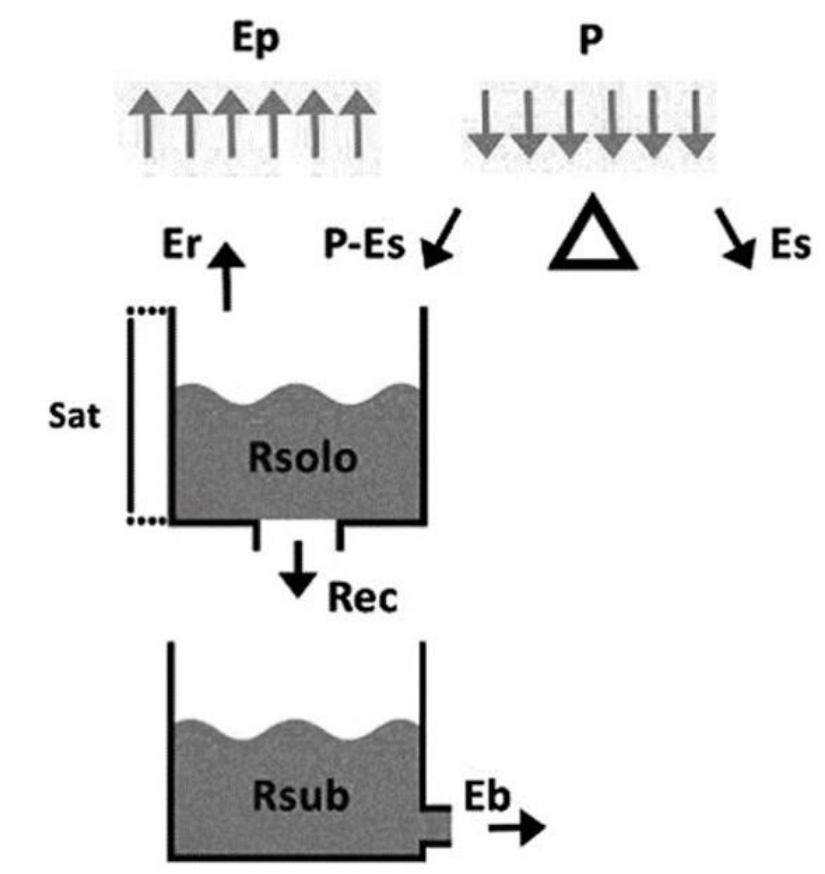

Figure 3. Working scheme of the monthly SMAP model. Es (stands for surface runoff), P (precipitation), Er (actual evapotranspiration), $\mathrm{Ep}$ (potential evapotranspiration), Eb (base runoff), K (recession constant), Rsolo (soil reservoir), Rsub (underground reservoir), Sat (soil saturation capacity) and Rec (underground recharge). Source: Lopes et al. (1981). 
The reference values for NASH, suggested by Andrade et al. (2017), are classified as: good (between 0.4 and 0.6 ), very good (0.6 and 0.8) and excellent (above 0.8 ). Being its maximum value corresponding to 1 , which indicates/means a perfect adjustment between the modeled and the observed data. Table 2 brings calibrated SMAP model parameters to the NIS representative basins.

\section{The linear regression model}

In order to estimate the streamflow rates for the hydroelectric power stations that do not have a calibrated SMAP model, the Linear Regression model was used. It considers, empirically, the relationships between the observed variables without necessarily considering the physical behavior of the process; being it easy to adjust and validate (Malfatti et al., 2018).

In this study, the first stage of the regression model took place through the standardization of the monthly series of naturalized streamflows from the ONS using Equation 7:

$$
Z_{i, j, k}=\frac{q_{i, j, k}-\overline{q_{i, j}}}{o_{i, j}}
$$

where $Z$ stands for the normalized streamflow; $i$ the number of months (ranging from 1 to 12); $\mathrm{k}$ the number of years (ranging from 1931 to 2008); $\mathrm{j}$ the number of stations (in total 185); qi,j,k the naturalized streamflow of station $j$ in month $i$ in year $k$, qi,j the matrix that represents the average of all months and stations, and $\mathrm{i}, \mathrm{j}$ the matrix that represents the standard deviation of the monthly series of all stations.

After standardization, linear regression of ONS naturalized streamflows was performed and the parameters of each station that does not have the calibrated SMAP (totaling 161 stations) were obtained, considering all other stations as explanatory variables (totaling 24 stations). Therefore, linear regression was given by Equation 8:

$$
Z_{\mathrm{i}, \mathrm{pj}, \mathrm{k}}=\sum_{\mathrm{pk}=1}^{\mathrm{pk}=24} \mathrm{Z}_{\mathrm{i}, \mathrm{pk}, \mathrm{k}} \cdot \beta_{\mathrm{i}, \mathrm{pk}}
$$

where pk stands for the streamflows from the 24 basins obtained through the SMAP model (ranging from 1 to 24), pj stands for the stations that do not have the calibrated SMAP (ranging from 1 to 161) and i,pk stand for regression coefficients.

Figure 4 shows the performance of the linear regression model in estimating the streamflow of the 161 stations, which do not have the calibrated SMAP model, through the NASH.

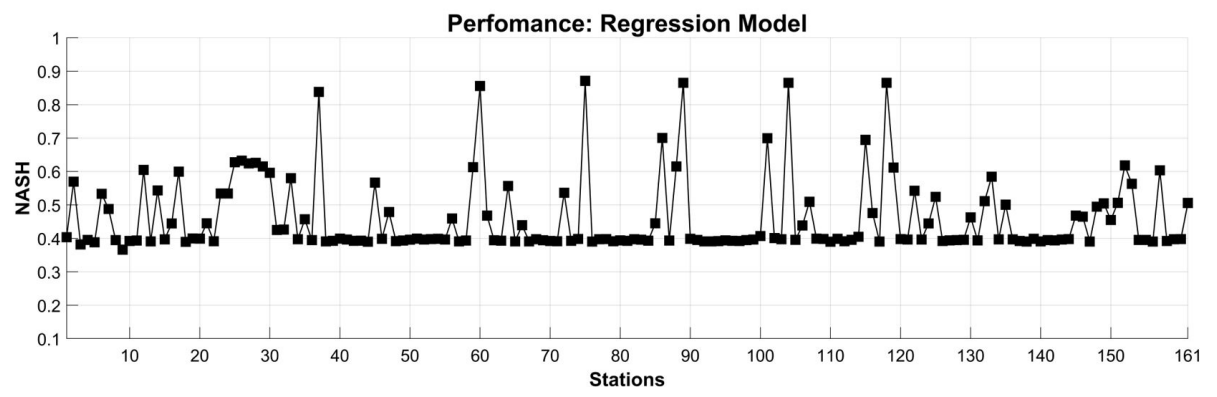

Figure 4. Performance of the linear regression model in estimating the affluent natural streamflow of the NIS stations through the NASH.

\begin{tabular}{|c|c|c|c|c|c|c|c|c|}
\hline Basins & Area & TUin & EBin & Str & Pes & Crec & $\mathbf{K}$ & NASH \\
\hline Emborcação & 29000 & 55 & 96 & 900 & 3.2 & 20 & 2 & 0.82 \\
\hline Nova Ponte & 15300 & 52 & 70 & 1100 & 3 & 25 & 2 & 0.85 \\
\hline Itumbiara & 51011 & 52 & 170 & 2000 & 3.1 & 9 & 2 & 0.87 \\
\hline São Simão & 85729 & 60 & 349 & 2100 & 4.6 & 7 & 2 & 0.86 \\
\hline Furnas & 50464 & 48 & 221 & 1400 & 2.2 & 26 & 2 & 0.90 \\
\hline Água Vermelha & 89436 & 55 & 449 & 1200 & 3.3 & 20 & 2 & 0.87 \\
\hline Nova Avanhandava & 62300 & 67 & 352 & 1200 & 4.6 & 10 & 3 & 0.86 \\
\hline Porto Primavera & 190760 & 54 & 1071 & 1400 & 3.3 & 20 & 3 & 0.90 \\
\hline Rosana & 100799 & 65 & 1149 & 1300 & 3.4 & 22 & 2 & 0.82 \\
\hline Itaipú & 149000 & 59 & 2204 & 1000 & 2.9 & 50 & 1 & 0.87 \\
\hline Santa Cecília & 16694 & 63 & 110 & 2000 & 3.5 & 8 & 3 & 0.85 \\
\hline Salto Caxias & 57000 & 61 & 762 & 400 & 1.8 & 70 & 1 & 0.90 \\
\hline Itá & 44500 & 78 & 513 & 600 & 3.7 & 15 & 1 & 0.95 \\
\hline Dona Francisca & 14014 & 92 & 120 & 1900 & 7 & 2 & 1 & 0.86 \\
\hline Três Marias & 50600 & 45 & 85 & 1300 & 2.3 & 18 & 1 & 0.88 \\
\hline Sobradinho & 447825 & 31 & 541 & 1800 & 2.5 & 50 & 6 & 0.90 \\
\hline Xingó & 110275 & 22 & 0 & 500 & 2.5 & 1 & 1 & 0.90 \\
\hline Serra da Mesa & 50975 & 63 & 107 & 1800 & 3.7 & 3 & 2 & 0.86 \\
\hline Lajeado & 134543 & 59 & 163 & 1350 & 3.9 & 4.5 & 1 & 0.92 \\
\hline Tucuruí & 572482 & 59 & 919 & 1200 & 5 & 4 & 1 & 0.91 \\
\hline Belo monte & 480000 & 72 & 588 & 2580 & 10 & 0.54 & 1 & 0.89 \\
\hline Teles pires & 90707 & 61 & 382 & 1300 & 3.8 & 9.3 & 2 & 0.90 \\
\hline São Luiz do Tapajós & 362293 & 56 & 1684 & 1300 & 3.8 & 6 & 2 & 0.88 \\
\hline Santo Antônio & 988873 & 71 & 3283 & 2700 & 6.4 & 1.64 & 2 & 0.85 \\
\hline
\end{tabular}

Table 2. Parameters of the calibrated SMAP model for the basins representing the NIS. 
Thus, with the coefficients obtained from the ONS naturalized streamflow series and the streamflow obtained through the SMAP model with the data from the CORDEX models, the streamflow for the climate change scenarios for the other stations were obtained (totaling 185 stations), using the linear regression parameters.

\section{NEA calculation}

From the monthly natural streamflows obtained for each hydroelectric utilization, it was possible to estimate the NEA. According to the Operador Nacional do Sistema (2017), it is calculated from natural streamflows and productivity equivalent to the storage of $65 \%$ of the useful volume of reservoirs of hydroelectric utilizations, being obtained on daily, weekly, monthly or annual basis, and also by basin and subsystem, according to the hydroelectric utilization systems existing in the configurations of hydrographic basins and electrical subsystems, through the expression:

$$
\operatorname{NEA}_{\text {basin }}(\mathrm{t})=\sum_{\mathrm{i}=1}^{\mathrm{m}}\left[\mathrm{Q}_{\text {nat }}(\mathrm{j}, \mathrm{t}) \cdot \mathrm{p}(\mathrm{j})\right]
$$

where $t$ is the interval of calculation time of the NEA; $i$ is the use belonging to the system of use of the basin considered; Qnat is the natural streamflow of utilization in the time interval considered; $\mathrm{p}$ is the average productivity of the turbine-generator set of hydroelectric use, referring to the drop obtained by the difference between the amount level, corresponding to a storage of $65 \%$ of the useful volume, and the average level of the leakage channel; $j$ use belonging to the system of use of the subsystem considered; and $\mathrm{m}$ is the number of uses existing in the system of uses.

\section{Statistical analysis of projections}

For statistical analysis of the projections, two methods were used: the seasonal anomalies calculation and the Mann-Kendall-Sen non-parametric trend test. For the seasonal anomalies calculation of the streamflow rates and NEA, RCM data were used for the projections related to the RCP 4.5 and RCP 8.5 scenarios (from 2007 to the end of the 21 st century) and the historical scenario for the 20th century (1951-1999), according to the Equation 10:

$$
\mathrm{A}_{\text {anual }}=\frac{\left(\mathrm{P}_{\mathrm{XXI}}^{\mathrm{a}}-\mathrm{P}_{\mathrm{XX}}^{\mathrm{a}}\right)}{\mathrm{P}_{\mathrm{XX}}^{\mathrm{a}}} \cdot 100
$$

where $\mathrm{P}_{\mathrm{XXI}}^{\mathrm{a}}$ is the annual average of the projection variables for the 21 st century scenarios and $\mathrm{P}_{\mathrm{XX}}^{\mathrm{a}}$ is the annual average of the twentieth century variables.

On the other hand, the Mann-Kendall-Sen nonparametric test was used to verify trends in the streamflow and NEA series in the projections under RCP 4.5 and RCP 8.5 scenarios for the 21st century. According to Moreira \& Naghettini (2016), the Mann-Kendall-Sen nonparametric test has been widely used for hydrological studies and is recommended by the World Meteorological Organization (WMO) for temporal series analysis of environmental variables.
As well as the anomaly calculation, for Mann-Kendall-Sen trend tests, the 21 st century projections were compared to the 20 th century characteristics. To this end, they were standardized according to Equation 11:

$Z=\frac{\left(X_{X X I}^{\mathrm{j}}-\bar{X}_{\mathrm{XX}}\right)}{\mathrm{o}_{\mathrm{XX}}}$

where $Z$ stands for the series of standardized 21 st century scenarios; $\mathrm{X}_{\mathrm{XXI}}^{\mathrm{j}}$ is the annual average series under RCP 4.5 and RCP 8.5 scenarios for one year " $\mathrm{j}$ "; $\overline{\mathrm{X}}_{\mathrm{XX}}$ stand for the averages of the annual average series of the twentieth century; and $\sigma_{\mathrm{XX}}$ stand for the standard deviations of the annual average series of the twentieth century.

Thus, according to Wagesho et al. (2012), the Mann-Kendall test statistic for a series $(\mathrm{Z} 1, \mathrm{Z} 2, \ldots, \mathrm{Zn})$ from a sample of $\mathrm{n}$ independent and identically distributed random variables, is given in Equation 12:

$$
S=\sum_{i=1 j=i+1}^{n-1} \sum_{j=1}^{n} \operatorname{signal}\left(Z_{j}-Z_{i}\right)
$$

where $\mathrm{S}$ stands for the values of the series in annual time intervals; $i$ and $j$ are the time indexes, and $n$ is the number of elements of the series (Moreira \& Naghettini, 2016). The term signal $(\mathrm{Zj}-\mathrm{Zi}$ ) is the result of Equation 13:

$$
\operatorname{signal}\left(Z_{j}-Z_{i}\right)=\left\{\begin{array}{c}
+1 \operatorname{se}\left(Z_{j}-Z_{i}\right)>0 \\
0 \operatorname{se}\left(Z_{j}-Z_{i}\right)=0 \\
-1 \operatorname{se}\left(Z_{j}-Z_{i}\right)<0
\end{array}\right.
$$

For the zero hypothesis Test H0 (which considers not to have a positive trend), the TAU variables and $\mathrm{p}$-value were used. The TAU variable is related to the correlation classification coefficient and quantifies the monotonic association, given by Equation 14:

$$
\mathrm{TAU}=\frac{\mathrm{S}}{\frac{1}{2} \mathrm{n}(\mathrm{n}-1)}
$$

where $n$ is the size of the series.

$\mathrm{H} 0$ is accepted into Mann-Kendall's TAU when the test is less than a critical value named $\alpha$, which for this study was $\alpha=0.05$ (for a statistical significance of $95 \%$ ), i.e. for TAU $<\alpha$, the series has no positive trend. Otherwise, that is, for TAU $\geq \alpha$, TS has a positive trend. On the other hand, the p-value of the $\mathrm{S}$ statistic considers the $\mathrm{H} 0$ true, for $\mathrm{p}$-value $>\alpha$ and false for $\mathrm{p}$-value $\leq \alpha$ (Moreira \& Naghettini, 2016).

The Sen Estimator, in turn, provides the magnitude of the trends detected. According to Moreira \& Naghettini (2016), it is estimated by q statistic, given by Equation 15:

$Q_{i j}=\frac{X_{j}-X_{i}}{j-i} \operatorname{com~} i<j$

where $\mathrm{Xi}$ and $\mathrm{Xj}$ are related to the variable values under study in $\mathrm{i}$ and $j$ times (Moreira \& Naghettini, 2016). The positive or negative value for $\mathrm{Q}$ indicates increasing or decreasing trend, respectively. 


\section{RESULTS AND DISCUSSION}

The average percentage anomalies behavior of annual naturalized streamflows and NEA shown by the CORDEX models for the periods 2010-2039, 2040-2069 and 2070-2099, indicated projections with more intense reductions in the RCP 8.5 scenario compared to the RCP 4.5 scenario for the three analyzed periods and for the North, Northeast and Southeast/Midwest sectors (see Figures 5 and 6). This fact may relate to the greater temperature increase projected by the RCP 8.5 scenario, resulting in a greater increase in the ETP projected for the 21st century, as shown in the work of Guimarães et al. (2016) for Brazil's Northeastern region. The possible increase in ETP directly impacts on significant reductions in naturalized streamflows for most stations in those sectors, as shown in Figure 7. In addition, the indication of a greater reduction in annual naturalized streamflows and NEA in the RCP 8.5 scenario suggests that most stations of the NIS reservoirs are sensitive to the greenhouse gas emissions increase.

In the first period (2010-2039), most models indicated a greater NEA reduction possibility with anomaly magnitudes in the NIS between $-5 \%$ and $-25 \%$ in the RCP 8.5 scenario, as shown in Figure 5. This result occurred mainly due to some models that presented a reduction of less than $-25 \%$ in the North and Northeast sectors. In the South sector, however, most models indicated an annual naturalized streamflows and NEA increase (see Figures 5, 6 and 7), with some models and model medians, respectively, presenting magnitudes greater than $5 \%$. The possible increase in naturalized streamflows projections for the South sector had already been demonstrated in previous works using data from the CMIP3 and CMIP5 models, the works of Silveira et al. (2014, 2016, 2019) and Ribeiro Neto et al. (2016) are examples.
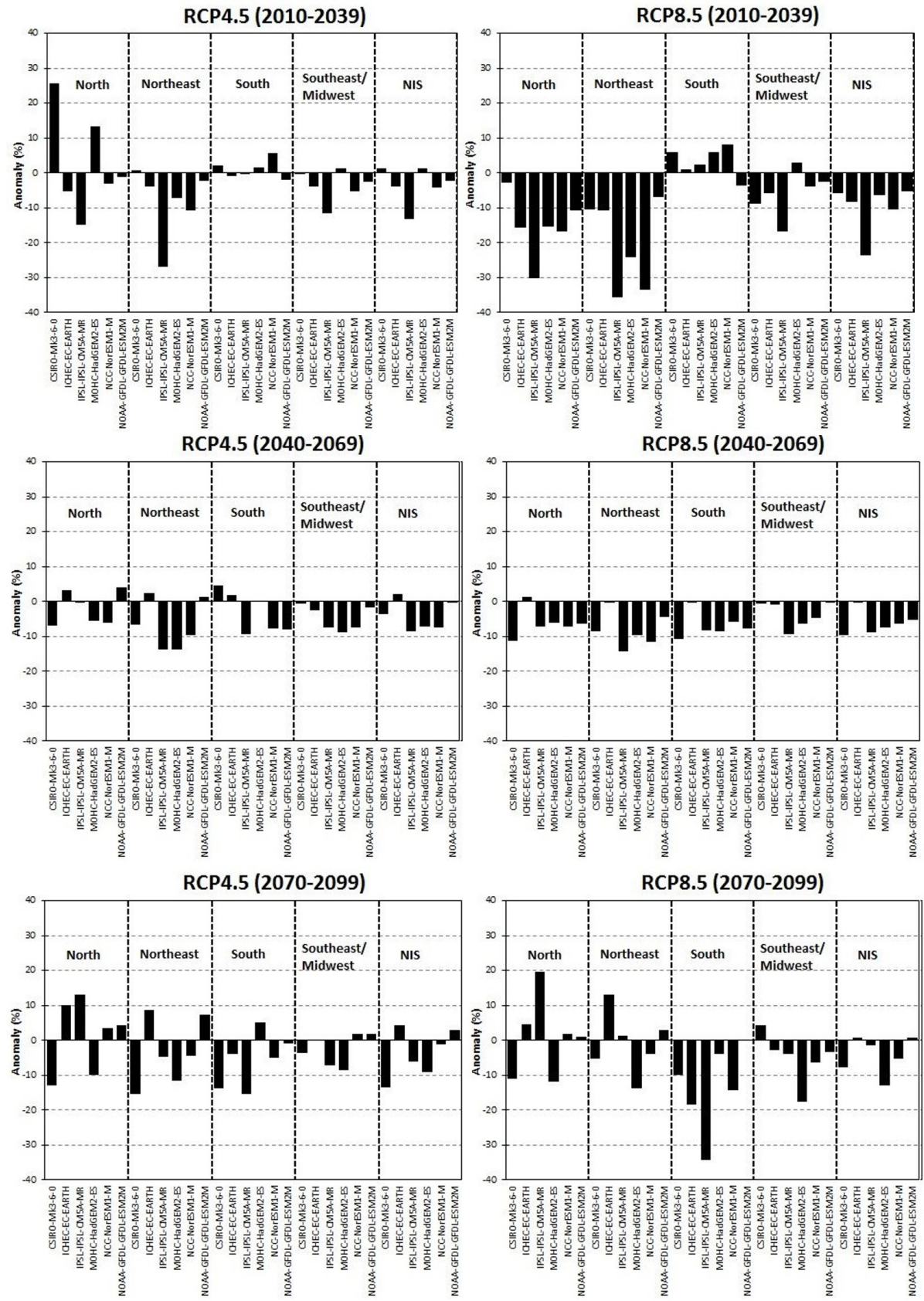

Figure 5. Annual NEA anomalies percentage under RCP4.5 and RCP8.5 scenarios for the subsystems that comprise the NIS. 

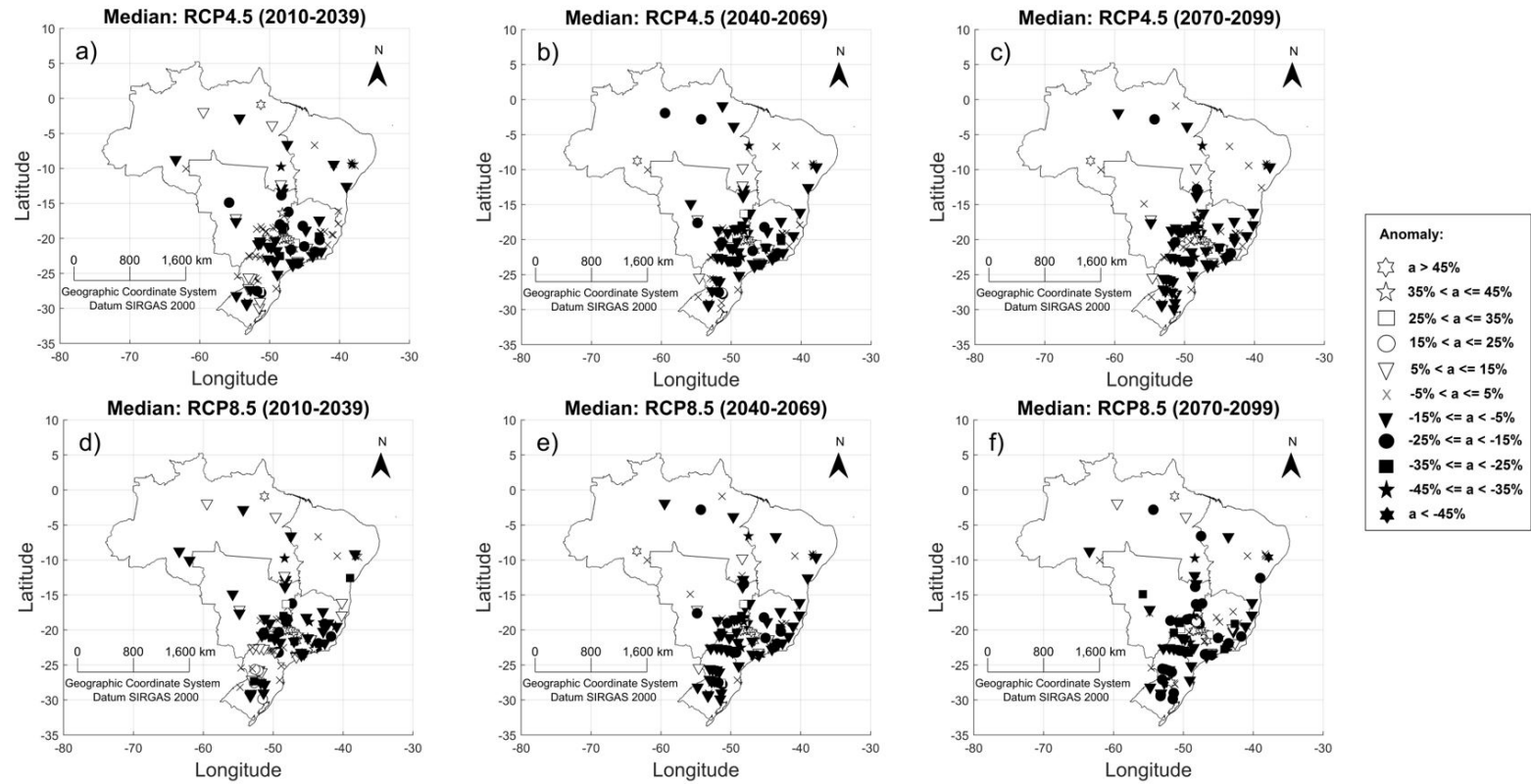

Figure 6. Median of annual streamflow anomalies average of CORDEX models, under RCP 4.5 scenarios in the period (a) 2010-2039; (b) 2040-2069; (c) 2070-2099 and RCP 8.5; (d) 2010-2039; (e) 2040-2069; (f) 2070-2099.

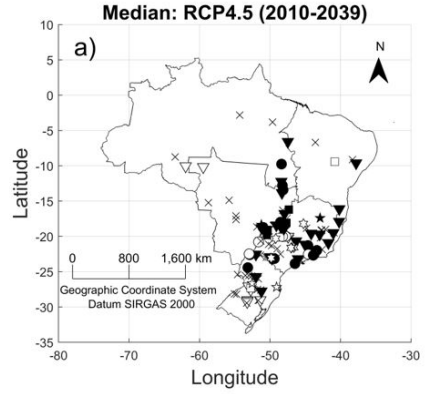

Median: RCP8.5 (2010-2039)

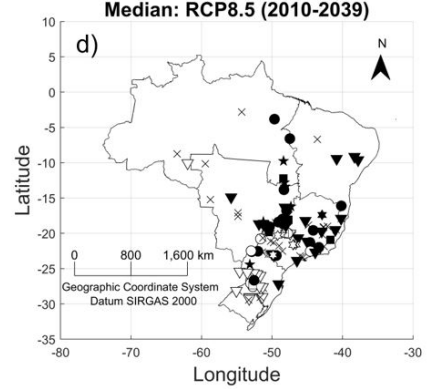

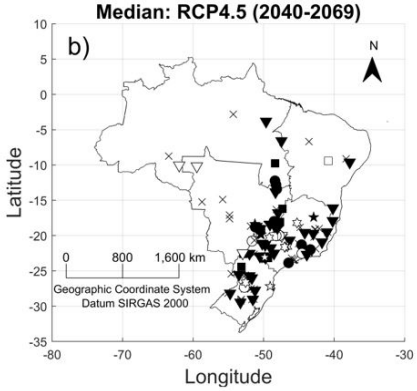

Median: RCP8.5 (2040-2069)

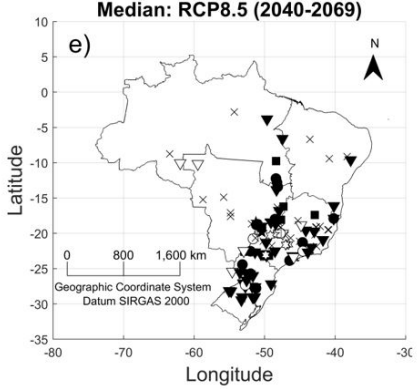

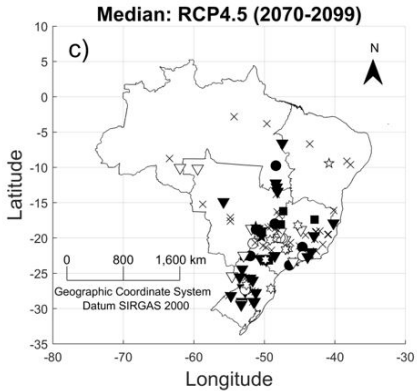

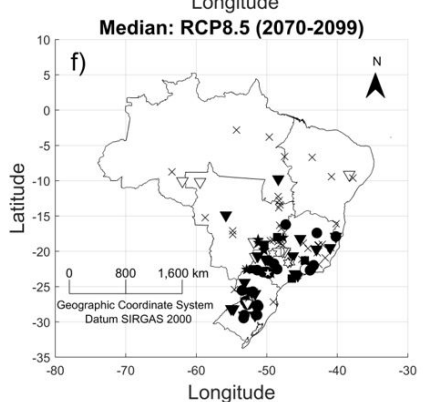

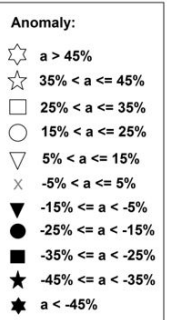

Figure 7. Median of annual NEA anomalies average of the CORDEX models, for RCP 4.5 scenarios in the period (a) 2010-2039; (b) 2040-2069; (c) 2070-2099 and RCP 8.5; (d) 2010-2039; (e) 2040-2069; (f) 2070-2099.

As well as in the period 2010-2039, in the period 2040-2069, the annual NEA and naturalized streamflows average percentage anomalies also indicated a reduction for most NIS models and stations for all sectors and scenarios. However, from 2070 to 2099 and for the North and Northeast sectors, the models were uncertain, with no convergence in the average percentage anomalies of annual naturalized streamflows and NEA. The CSIRO-MK3-6-0 and MOHC-HadGEM2-ES models, for example, indicated a naturalized streamflows and NEA reduction, while the ICHEC-EC-EARTH, IPSL-IPSL-CM5A-MR and NOAA-GFDL-GFDL-ESM2M models suggested an increase. For the other sectors, most models indicated a naturalized streamflows and NEA reduction. The results dispersion on the annual naturalized streamflows and NEA average anomalies for the North and Northeast sectors in the last period suggests a possible increase in the uncertainties of the CORDEX models projections over time.

Analyzing the CORDEX models set for the RCP 4.5 and RCP 8.5 scenarios of annual naturalized streamflows and NEA from 2010 to 2099, which presented significant trend declivities with the Mann-Kendall Sen test, there is clear evidence that the greenhouse gas emissions increase suggests a greater impact on electricity generation for the Brazilian electricity sector (see Figures 8 and 9). For, in most cases, the declivity module is always greater for the RCP 8.5 scenario in comparison to the RCP 4.5 one. These results are similar to the ones obtained by Silveira et al. $(2014,2016,2019)$ with CMIP5 data. 

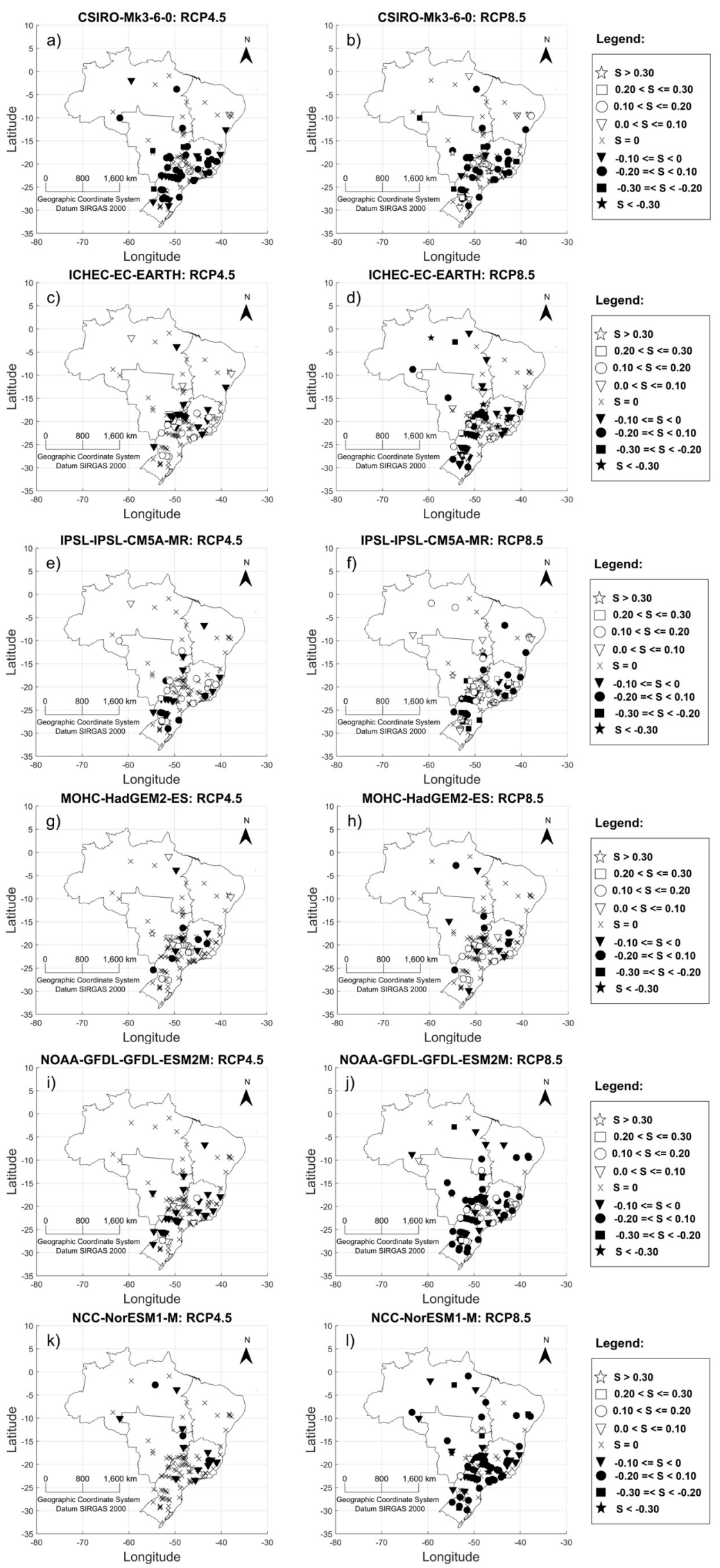

Figure 8. Trend, according to the Mann-Kendall-Sen method of the standardized annual streamflow average, referring to the RCP 4.5 and RCP 8.5 Scenarios of the CORDEX for the period 2010-2099. 

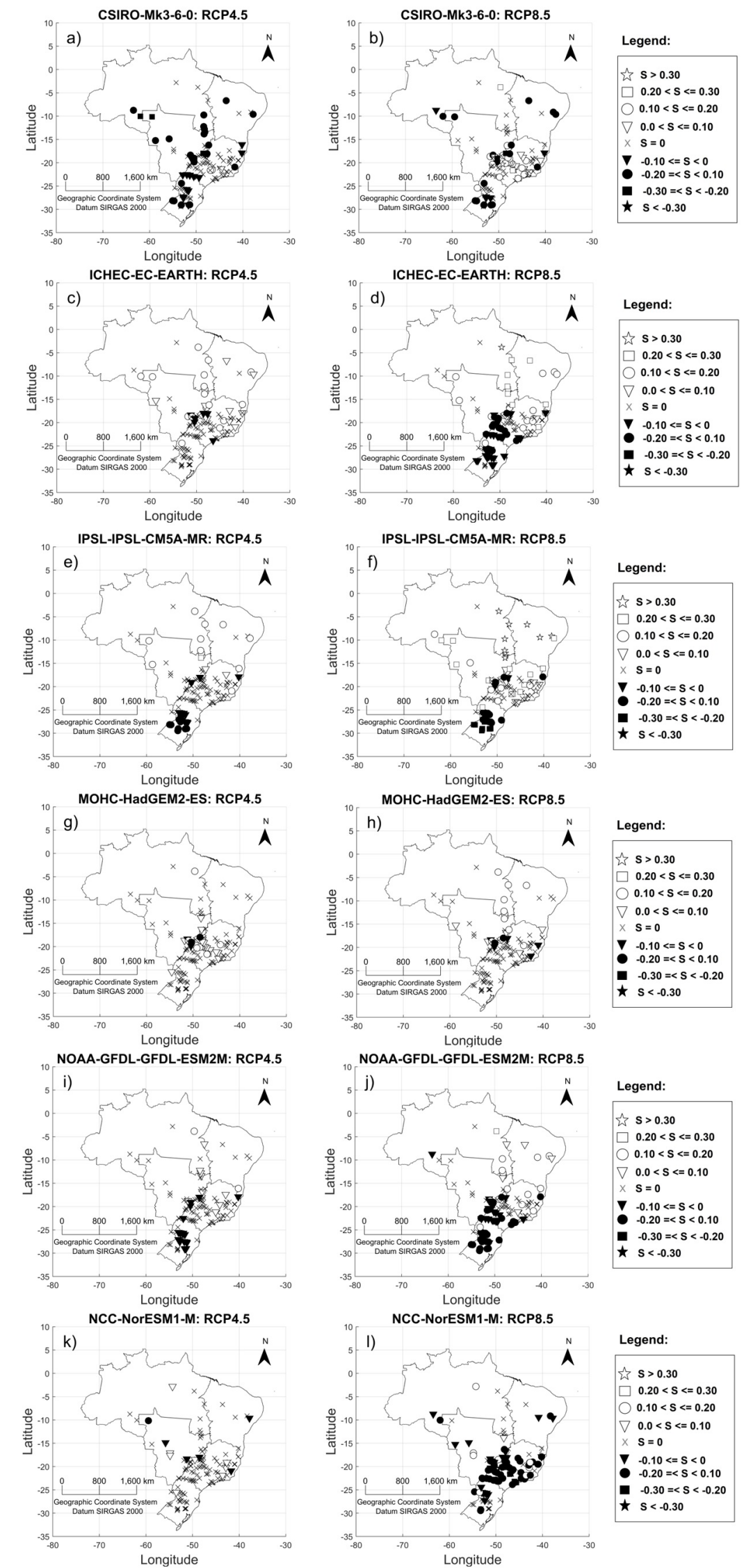

Figure 9. Trend, according to the Mann-Kendall-Sen method of standardized annual NEA average, referring to the RCP 4.5 and RCP 8.5 Scenarios of the CORDEX for the period 2010-2099. 
In the North and Southeast/Midwest sectors, most models and stations indicated a negative trend in the annual naturalized streamflows and NEA in both scenarios. The magnitude, for most models, was up to -0.30 in the RCP 8.5 scenario for the two variables analyzed. In addition, for the South and Northeast sectors, most stations, for some models, indicated a positive trend. Whereas for others, the majority of stations indicated a negative trend. Thus, for these two sectors, the models showed uncertainties regarding the declivity signs.

\section{CONCLUSION}

Climate has strong influence on society development, as it directly interferes in the environment, agriculture, air quality, economy, energy sector, among others. This is mainly due to extreme events, such as floods, severe droughts, etc. Long-term water and energy planning makes it possible to reduce social and economic impacts on several sectors, as it avoids episodes of interruption in the water and electricity supply necessary for its full operation. Thus, the analyses proposed by the present study aimed at identifying projections patterns for naturalized streamflows and NEA for the NIS regarding the impacts associated with the climatic changes of the CORDEX models for the RCP 4.5 and RCP 8.5 scenarios. For, such information can be used by the decision makers to better manage water and energy resources in order to minimize the impacts of the mentioned scenarios.

Most models showed projections with possible reductions in annual naturalized streamflows and NEA more intense in the RCP 8.5 scenario than in the RCP 4.5 one, for the three analyzed periods and for the North, Northeast and Southeast/Midwest sectors. Such a result reflected both in the average percentage anomalies and in the trend declivities.

In the South sector, for the period 2010-2039, most models indicated an annual naturalized streamflows and NEA increase with some models and model medians, respectively, presenting magnitudes greater than $5 \%$. The projections for the possible naturalized streamflows increase for the South sector, had already been demonstrated in previous works, using data from the CMIP3 and CMIP5 models. Obtaining similar results from the CMIP3, CMIP5 and CORDEX databases shows the cohesion in the methodologies adopted for the projection of climatic variables. Hence, recent studies end up contributing to the confirmation of past studies results, respecting the uncertainties associated with the process.

The possible reduction in water and energy availability in the North, Northeast and Southeast/Midwest sectors shown in this study demonstrates possible impacts from conflicts among multiple uses, a possible economy downturn due to water and energy reduction for agriculture and industry, as well as shortages in cities. Furthermore, in addition to the possible increased demand for electricity in Brazil over the next few years, that could lead to a crisis in the country's electricity sector, which could influence changes in the energy matrix due to the risk of not being met by the current matrix. As in the case of investments in non-renewable energy, causing positive feedback for climate change and, consequently, intensifying its damage to the entire climate system. On the other hand, it could influence investment in renewable sources (wind and solar, for example), so that they can take greater participation in the Brazilian electricity matrix. However, for the latter, a very complex policy with investment in technologies and labor training is necessary, so that, in the long term, this generation cost becomes cheaper for the country.

\section{ACKNOWLEDGEMENTS}

The authors acknowledge the Fundação Cearense de Apoio ao Desenvolvimento Científico e Tecnológico (FUNCAP), the Coordenação de Aperfeiçoamento de Pessoal de Nível Superior (CAPES) and the Conselho Nacional de Desenvolvimento Científico e Tecnológico (CNPq) for financial support.

\section{REFERENCES}

Al-Mutrafi, H., Zubari, W., El-Sadek, A., \& Abdel Gelil, I. (2018). Assessment of the water-energy nexus in the municipal water sector in Eastern Province, Saudi Arabia. Computational Water, Energy, and Environmental Engineering, 7(1), 1-26. http://dx.doi. org/10.4236/cweee.2018.71001.

Andrade, C. W. L., Montenegro, S. M. G. L., Lima, J. R. S., Montenegro, A. A. A., \& Magalhães, A. G. (2017). Modelagem hidrológica sob escassez de dados na Bacia do Alto Mundaú, Nordeste do Brasil. Journal of Environmental Analysis and Progress, 2(3), 227-238. http:/ / dx.doi.org/10.24221/jeap.2.3.2017.1443.227-238.

Capozzoli, C. R., Cardoso, A. O., \& Ferraz, S. E. T. (2017). Padrões de variabilidade de vazão de rios nas principais bacias brasileiras e associação com índices climáticos. Revista Brasileira de Meteorologia, 32(2), 243-254. http://dx.doi.org/10.1590/0102-77863220006.

Empresa de Pesquisa Energética - EPE. (2018). Balanço energético nacional 2018: ano base 2017. Rio de Janeiro: EPE.

Fang, G. H., Yang, J., Chen, Y. N., \& Zammit, C. (2015). Comparing bias correction methods in downscaling meteorological variables for a hydrologic impact study in an arid area in China. Hydrology and Earth System Sciences, 19(6), 2547-2559. http://dx.doi.org/10.5194/ hess-19-2547-2015.

Fernandes, R. O., Silveira, C. S., Studart, T. M. C., \& Souza Filho, F. A. (2017). Reservoir yield intercomparison of large dams in Jaguaribe Basin-CE in climate change scenarios. Revista Brasileira de Recursos Hidricos, 22(0), 1-11. http:/ / dx.doi.org/10.1590/23180331.011716033.

Gondim, R., Silveira, C., Souza Filho, F. A., Vasconcelos Júnior, F. C., \& Cid, D. (2018). Climate change impacts on water demand and availability using CMIP5 models in the Jaguaribe basin, semiarid Brazil. EnvironmentalEarth Sciences, 77(15), 1-14. http://dx.doi. org/10.1007/s12665-018-7723-9.

Guimarães, S. O., Costa, A. A., Vasconcelos Júnior, F. C., Silva, E. M., Sales, D. C., Araújo Júnior, L. M., \& Souza, S. G. (2016). Projeções de Mudanças Climáticas sobre o Nordeste Brasileiro 
dos Modelos do CMIP5 e do CORDEX. Revista Brasileira de Meteorologia, 31(3), 337-365. http://dx.doi.org/10.1590/0102778631320150150 .

Hargreaves, G. H. (1994). Defining and using reference evapotranspiration. Journal of Irrigation and Drainage Engineering, 120(6), 1132-1139. http://dx.doi.org/10.1061/(ASCE)07339437(1994)120:6(1132).

Ho, J. T., Thompson, J. R., \& Brierley, C. (2016). Projections of hydrology in the Tocantins-Araguaia Basin, Brazil: uncertainty assessment using the CMIP5 ensemble. Hydrological Sciences Journal, 61(3), 551-567. http://dx.doi.org/10.1080/02626667.2015.1057513.

Intergovernmental Panel on Climate Change - IPCC. (2014). Climate Change 2014: impacts, adaptation, and vulnerability. Part A: global and sectoral aspects: contribution of Working Group II to the Fifth Assessment Report of the Intergovernmental Panel on Climate Change. Cambridge: Cambridge University Press.

International Energy Agency - IEA. (2020). Power sector CO2 emissions continue to rise. Paris: IEA. Retrieved in 2020, February 7, from https://www.iea.org/

Kjellström, E., Bärring, L., Nikulin, G., Nilsson, C., Persson, G., \& Strandberg, G. (2016). Production and use of regional climate model projections: a Swedish perspective on building climate services. Climate Services, 2-3, 15-29. PMid:28345063. http://dx.doi. org/10.1016/j.cliser.2016.06.004.

Lopes, J. E. J., Braga Junior, B. P. F., \& Conejo, J. G. L. (1981). Simulação hidrológica: aplicações de um modelo simplificado. In Anais do III Simpósio Brasileiro de Recursos Hídricos (pp. 42-62). Fortaleza: SBRH.

Malfatti, M. G. L., Cardoso, A. O., \& Hamburger, D. S. (2018). Modelo empírico linear para previsão de vazão de rios na usina hidrelétrica de Itaipu - Bacia do Rio Paraná. Revista Brasileira de Meteorologia, 33(2), 257-268. http://dx.doi.org/10.1590/01027786332005 .

Mendes, C. A. B., Beluco, A., \& Canales, F. A. (2017). Some important uncertainties related to climate change in projections for the Brazilian hydropower expansion in the Amazon. Energy, 141, 123-138. http://dx.doi.org/10.1016/j.energy.2017.09.071.

Moreira, J. G. V., \& Naghettini, M. (2016). Detecção de Tendências Monotônicas Temporais e Relação com Erros dos Tipos I e II: Estudo de Caso em Séries de Precipitações Diárias Máximas Anuais do Estado do Acre. Revista Brasileira de Meteorologia, 31(4), 394-402. http://dx.doi.org/10.1590/0102778631231420140155.

Nash, J., \& Sutcliffe, J. V. (1970). River flow forecasting through conceptual models part IA discussion of principles. Journal of Hydrology), 10(3), 282-290. http://dx.doi.org/10.1016/00221694(70)90255-6.
Oliveira, V. A., Mello, C. R., Viola, M. R., \& Srinivasan, R. (2017). Assessment of climate change impacts on streamflow and hydropower potential in the headwater region of the Grande river basin, Southeastern Brazil. International Journal of Climatology, 37(15), 5005-5023. http://dx.doi.org/10.1002/joc.5138.

Operador Nacional do Sistema - ONS. (2017). O Operador Nacional do Sistema elétrico e os procedimentos de rede: submódulo 23.5 critérios para estudos hidrológicos: revisão 1.0. Brasília: ONS.

Operador Nacional do Sistema - ONS. (2020). O sistema interligado nacional. Brasília: ONS. Retrieved in 2020, February 7, from http:/ / www.ons.org.br

Pardoe, J., Conway, D., Namaganda, E., Vincent, K., Dougill, A. J., \& Kashaigili, J. J. (2017). Climate change and the water-energyfood nexus: insights from policy and practice in Tanzania. Climate Policy, 18(7), 863-877. http://dx.doi.org/10.1080/14693062.201 7.1386082 .

Prado, F. A., Athayde, S., Mossa, J., Bohlman, S., Leite, F., \& OliverSmith, A. (2016). How much is enough? An integrated examination of energy security, economic growth and climate change related to hydropower expansion in Brazil. Renewable \& Sustainable Energy Reviews, 53,1132-1136. http://dx.doi.org/10.1016/j.rser.2015.09.050.

Ramirez-Villegas, J., \& Khoury, C. K. (2013). Reconciling approaches to climate change adaptation for Colombian agriculture. Climatic Change, 119(3-4), 575-583. http://dx.doi.org/10.1007/s10584013-0792-6.

Reboita, M. S., Dias, C. G., Dutra, L. M. M., Rocha, R. P., \& Llopart, M. (2018). Previsão climática sazonal para o Brasil obtida através de modelos climáticos globais e regional. Revista Brasileira de Meteorologia, 33(2), 207-224. http://dx.doi.org/10.1590/01027786332001.

Reboita, M. S., Gan, M. A., Rocha, R. P., \& Ambrizzi, M. (2010). Regimes de precipitação na América do Sul: uma revisão bibliográfica. Revista Brasileira de Meteorologia, 25(2), 185-204. http://dx.doi. org/10.1590/S0102-77862010000200004.

Ribeiro Neto, A., Paz, A. R., Marengo, J. A., \& Chou, S. C. (2016). Hydrological Processes and Climate Change in Hydrographic Regions of Brazil. Journal of Water Resource and Protection, 8(12), 1103-1127. http://dx.doi.org/10.4236/jwarp.2016.812087.

Sales, D. C., Costa, A. A., Silva, E. M., Vasconcelos Júnior, F. C., Cavalcante, A. M. B., Medeiros, S. S., Marin, A. M. P., Guimarães, S. O., Araújo Júnior, L. M., \& Pereira, J. M. R. (2015). Projeções de mudanças na precipitação e temperatura no nordeste brasileiro utilizando a técnica de downscaling dinâmico. Revista Brasileira de Meteorologia, 30(4), 435-456. http://dx.doi.org/10.1590/0102778620140075 .

Scanlon, B. R., Ruddell, B. L., Reed, P. M., Hook, R. I., Zheng, C., Tidwell, V. C., \& Siebert, S. (2017). The food-energy-water 
nexus: transforming science for society. Water Resources Research, 53(5), 3550-3556. http://dx.doi.org/10.1002/2017WR020889.

Schneider, U., Finger, P., Meyer-Christoffer, A., Rustemeier, E., Ziese, M., \& Becker, A. (2017). Evaluating the hydrological cycle over land using the newly-corrected precipitation climatology from the Global Precipitation Climatology Centre (GPCC). Atmosphere, 8(12), 52-59. http://dx.doi.org/10.3390/atmos8030052.

Silveira, C. S., Souza Filho, F. A., Lopes, J. E. G., Barbosa, P. S. F., \& Tiezzi, R. O. (2014). Análise das projeções de vazões nas bacias do setor elétrico brasileiro usando dados do IPCC-AR4 para o século XXI. Revista Brasileira de Recursos Hídricos, 19(4), 5971. http://dx.doi.org/10.21168/rbrh.v19n4.p59-71.

Silveira, C. S., Souza Filho, F. A., Vasconcelos Júnior, F. C., \& Martins, E. S. P. R. (2016). Projections of the Affluent Natural Energy (NEA) for the Brazilian electricity sector based on RCP 4.5 and RCP 8.5 scenarios of IPCC-AR5. Hydrology and Earth System Sciences Discussions, 1-18. http://dx.doi.org/10.5194/hess-2016-135.

Silveira, C. S., Vasconcelos Júnior, F. C., Souza Filho, F. A., Guimarães, S. O., Marcos Junior, A. D., Reis, G. N. L., \& Porto, V. C. (2019). Performance evaluation of AR5-CMIP5 models for the representation of seasonal and multi-annual variability of precipitation in Brazilian hydropower sector basins under RCP8.5 scenario. Hydrological Sciences Journal, 64(11), 1279-1296. http:// dx.doi.org/10.1080/02626667.2019.1612521.

Sorribas, M. V., Paiva, R. C. D., Melack, J. M., Bravo, J. M., Jones, C., Carvalho, L., Beighley, E., Forsberg, B., \& Costa, M. H. (2016). Projections of climate change effects on discharge and inundation in the Amazon basin. Climatic Change, 136(3-4), 555-570. http:// dx.doi.org/10.1007/s10584-016-1640-2.

Volosciuk, C., Maraun, D., Vrac, M., \& Widmann, M. (2017). A combined statistical bias correction and stochastic downscaling method for precipitation. Hydrology and Earth System Sciences, 21(3), 1693-1719. http://dx.doi.org/10.5194/hess-21-1693-2017.
Wagesho, N., Goel, N. K., \& Jain, M. K. (2012). Investigation of nonstationary in hydro-climatic variables at Rift Valley lakes basin of Ethiopia. Journal of Hydrology, 444-445, 113-133. http://dx.doi. org/10.1016/j.jhydrol.2012.04.011.

Zhang, X., Li, H., Deng, Z. D., Ringler, C., Gao, Y., Hejazi, M. I., \& Leung, L. R. (2018). Impacts of climate change, policy and Water-Energy-Food nexus on hydropower development. Renewable Energy, 116, 827-834. http://dx.doi.org/10.1016/j. renene.2017.10.030.

Zhou, Y., Ma, M., Gao, P., Xu, Q., Bi, J., \& Naren, T. (2019). Managing water resources from the energy - water nexus perspective under a changing climate: a case study of Jiangsu province, China. Energy Policy, 126, 380-390. http://dx.doi.org/10.1016/j.enpol.2018.11.035.

\section{Authors contributions}

Marx Vinicius Maciel da Silva: Manuscript structure, literature review, methods, analysis of the results and writing.

Cleiton da Silva Silveira: Study orientation, Manuscricpt structure, literature review, methods, analysis of the results and thecnical review of the manuscript.

Greicy Kelly da Silva: Thecnical review of the manuscript.

Wanderson Hugues de Vasconcelos Pedrosa: Thecnical review of the manuscript and translation to English.

Antônio Duarte Marcos Júnior: Downsload of the data and statistical correction using the accumulative distribution function range.

Francisco de Assis Souza Filho: Study orientation, Manuscricpt structure, literature review, methods, analysis of the results and thecnical review of the manuscript. 